\title{
Efficacy of soil amendments on agronomic traits, yield and nutritional quality of Sweet Corn (Zea mays L. var. saccharata)
}

\begin{abstract}
The different types of fertilizer and levels were evaluated to determine the optimum fertilizer type and level and as well to suggest the better agronomic practices for increasing yield and nutritional quality of sweetcorn. The experiment was carried out at the teaching and research farm of Obafemi Awolowo University during the 2018 early and late seasons. The experiment was a factorial $(2 \times 4 \times 6)$ experiment involvedtwo seasons, four fertilizer types (Urea, NPK, organomineral and Organic fertilizer) and six fertilizer levels $(0,25$, $50,75,100$ and $125 \mathrm{~kg} / \mathrm{ha}$ ). Data was collected on the agronomic, yield and nutritional quality of sweetcorn. The fresh kernel was evaluated at the time of harvest for total sugar content and proximate analysis. the data collected were subjected to analysis of variance (ANOVA) to determine the effects of treatments on the parameters and significant means were separated by Least Significant Difference (LSD) at (0.05) probability level.
\end{abstract}

The results of this study showed that season, fertilizer types and levels significantly affected the growth and yield of sweet corn. Fertilizer types and levels significantly enhanced the agronomic parameters subsequently resulted in higher yield. The significant effect of fertilizer types and levels is observed on the total sugar concentration of sweet corn. The NPK $100 \mathrm{~kg} /$ ha fertilizer type and level have the highest total sugar concentration which significantly different from others.

It is, therefore, concluded that NPK fertilizer type and $100 \mathrm{Kg}$ /ha significantly increased the growth, yield and nutritional quality of sweet corn.

Keywords: Zea mays var. saccharata, fertilizer, season
Volume 4 Issue 4 - 2020

\author{
Olufemi Victor Ajibola, Oluwatobi Nehemiah \\ Ogunmola, Julius Bamidele Amujoyegbe \\ Department of Crop Production and Protection, Obafemi \\ Awolowo University, Nigeria
}

Correspondence: Olufemi Victor Ajibola, Department of Crop Production and Protection, Obafemi Awolowo University, Nigeria, Email vicajibolfirst@gmail.com

Received: June 16, 2020 | Published: July 0I, 2020

\section{Introduction}

Sweet corn (Zea mays saccharata L.) is becoming a popular horticultural product in Nigeria and it is highly demanded due to it's sweeter taste when consumed. Sweet corn has a high premium over maize, has a short life and subsequently has a relatively higher price and it is assumed to be more profitable to be produced by farmers. However, sweet corn is facing some challenges such as low soil fertility and fertilizer types and levels to improve the soil health and thereby increase the agricultural produce. ${ }^{1}$

In Nigeria, it is observed that sweet corn production is very low due to low soil fertility and the optimum rate of an amendment needed to be applied. One of the ways of improving soil fertility is by supplementing the soil by organic and inorganic fertilizer that is beneficial to improve the soil fertility and agricultural quality and quantity. ${ }^{1}$

Sweet corn is a horticultural crop that has the potential to add to the realization of food security in Nigeria. ${ }^{2}$ Sweet corn is much in demand. Sweet corn requires additional agronomic improvement ${ }^{3}$ and development due to climatic changes. ${ }^{4}$

Enhancing productivity and profitability of maize through research on resource-use efficiency could lead to sustainable agricultural production, a considerable increase of food, and increased farmer income. Sweet corn production has low yield, low soil fertility and spacing in Nigeria. Efforts to improve soil fertility is through soil fertilization.
Application of fertilizer increases growth and yield of sweetcorn by increasing the magnitude of yield ${ }^{5,6}$ and. $^{7}$ Increase in yield attributing characters is associated with better plant nutrition and increased nutrient uptake, ${ }^{8}$ leading to high return on production costs. ${ }^{9}$ Nitrogen $(\mathrm{N})$ is a limiting factor for sweet corn production. Nitrogen fertilizer increase kernel yield and nutritional quality of sweet corn. When nitrogen is available, vegetative growth will be increased and improve per cent protein in kernels. Sweet corn production is often limited by nitrogen deficiency than other elements. Addition of urea $(46 \% \mathrm{~N})$ is assumed to decrease the level of deficiency of sweet corn plant to $\mathrm{N}$ nutrients. ${ }^{10}$ Application of urea fertilizer and manure can produce the highest cob corn. ${ }^{11}$ Use of enriched rice straw compost and recommended nitrogen fertilizer was recommended for sweet corn cultivation in Ultisol soil. ${ }^{12}$ Fertilization using organic fertilizer is expected to reduce the need for urea as well to improve soil fertility and soil health to support growth and increase the production of sweet corn.

Farmers often cultivate sweet corn with excessive ${ }^{10}$ nitrogen, which will damage soil fertility. Unfortunately, sweet corn production is mainly under urban farming and does not meet demand. The study was undertaken to determine the effect of fertilizer that willenhance growth, yield and nutritional qualities of sweet corn.

\section{Materials and methods}

The experiment was carried out at the Teaching and Research farms of Obafemi Awolowo University (OAU) Ile Ife, Osun State, Nigeria. The OAU is situated within the rain forest zone, Latitude 
$7^{\circ} 28^{\prime} \mathrm{N}$, Longitude $4^{\circ} 33^{\prime} \mathrm{E}$ at an elevation of about $244 \mathrm{~m}$ above sea level. The location experiences approximately 8 Months (March to October) of bimodal rainfall with the maximum in July and September of each year, with a 4 month (November to February) dry season with annual rainfall between 800 and $1500 \mathrm{~mm}$. Humidity is about $74 \%$ all year round, except in January when dry Hamattan wind blows. Temperature varies between 21 and $31^{\circ} \mathrm{C}$. Soils of the experimental site belong to the Iwo series derived from coarse-grained granite gneiss parent rock and classified as Ultisol (low base status forest soils). It is well-drained, greyish brown to brownish-red with predominantly high acidity clay - kaolinite. ${ }^{13}$

Soil samples were collected in different locations of the site using an Auger to a soil depth of about $15 \mathrm{~cm}$ and bulked to form a composite and analyzed at the Department of Soil and Land Resources Management laboratory for physical and chemical properties at the beginning of the cropping season.

The seed of sweet corn, cv. saccharata were collected from the agronomic unit of the Department of Crop Production and Protection, Obafemi Awolowo University. The soil was prepared using a disc plough run twice after which it was harrowed once using a disc. The experiment was a $2 \times 4 \times 6$ factorial design arranged in a randomized complete block design with three replication. The factors were: early and late season in 2018; 4 fertilizer types: organic, NPK, urea and organo-mineral, a mix of organic and NPK; and the fertilizer levels 0 , $25,50,75,100,125 \mathrm{kgN} \cdot \mathrm{ha}^{-1}$.

The soil was prepared and formed into flatbeds. Seeds were sown with a $0.3 \mathrm{~m}$ intra-row spacing and $0.7 \mathrm{~m}$ inter-row spacing corresponding to 96,192 plants $\cdot$ ha $^{-1}$. Fertilizer treatments were applied at 2 and 6 weeks after planting using the ring method around the plant. Application of herbicides was applied pre- (Atrazine $\left.{ }^{\circledR}\right)$ and post-

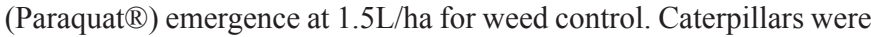
controlled with the insecticide Force ${ }^{\circledR}$, active ingredient Emamectin Benzoate 5\% WDG. Plant height, plant biomass, number of leaves, plant diameter, ear height, ear weight and leaf area on 5 randomly selected plants in row 2 and 6 . Data were taken at 3 and 5 weeks after sowing. Leaf area was determined with the formula according to. ${ }^{14}$ Yield $\cdot h^{-1}$ was determined. Sweet corn seeds were subjected to proximate analysis and sugar content to determine the chemical composition and total seed sugar composition following established methods ${ }^{15}$ andphenolic disulphuric acid method, respectively.

The data were subjected to analysis of variance using. ${ }^{21}$ Significant interactions were used to explain the results. If interactions were not significant means were separated using the Least Significant Difference. ${ }^{16}$

\section{Results}

Results of the chemical and physical properties of the soil in the experimental sites before the cropping season are presented in Table 1. The surface soil was slightly acidic with a pH of $4.93\left(\mathrm{H}_{2} \mathrm{O}\right)$ and $4.72\left(\mathrm{CaCl}_{2}\right)$ for the first planting and $\mathrm{pH}$ of $5.12\left(\mathrm{H}_{2} \mathrm{O}\right)$ and 4.75 $\left(\mathrm{CaCl}_{2}\right)$ for the second planting. The soil of the site was low in organic carbon; $1.18 \%$ and $1.17 \%$ for the first planting and the second planting respectively. It's also high in total nitrogen; 0.32 and 0.30 for the two plantings respectively (Table 1). When the values of sand and silt were compared with that of clay using textural triangle, the soil of the site was classified as sandy loam and classified as Alfisol. ${ }^{12}$ Table 1.

Table I Soil chemical and physical properties

\begin{tabular}{llll}
\hline Property & Properties & 2018 March & 2018 July \\
\hline Chemical & $\mathrm{pH}(\mathrm{H} 2 \mathrm{O})(\mathrm{I}: 2)$ & 4.93 & 5.12 \\
& $\mathrm{pH}(\mathrm{CaCl})$ & 4.72 & 4.75 \\
& Organic Carbon (\%) & 1.18 & 1.17 \\
& Organic Matter (\%) & 2.07 & 2.04 \\
& Total N (\%) & 0.32 & 0.3 \\
& Sand (\%) & 80 & 78 \\
& Silt (\%) & 10 & 12 \\
& Clay (\%) & 10 & 10
\end{tabular}

The effect of seasons, fertilizer types and levels on some agronomic traits at three weeks after sowing WAS. Seasons, fertilizer types and levels were noticed to significantly affect the agronomic traits of sweet corn measured at three weeks after sowing Table 2. While the interaction of season $\mathrm{x}$ fertilizer types was able to significantly improve the number of leaves, plant girth and ear height, the interaction of season $\mathrm{x}$ fertilizer levels only improved plant height and plant biomass significantly while the interaction between fertilizer types and fertilizer levels and season $\mathrm{x}$ fertilizer types $\mathrm{x}$ fertilizer levels were highly improved the agronomic traits measured significantly at three weeks after sowing.

Table 2 Mean squares from analysis of variance showing effect of fertilizer type and level on growth parameters, and ear height measured at 3 weeks after sowing

\begin{tabular}{|c|c|c|c|c|c|c|c|}
\hline Source & df & Plant height & Number of leaves & Plant diameter & Leaf area & Plant biomass & Ear height \\
\hline Season (S) & 1 & $21895.98 * *$ & $6.04 * *$ & $13.66 * *$ & $3577 \mid 8.68 * *$ & $295.85^{* *}$ & $|770.3|$ ** \\
\hline Replication(season) & 4 & 445.57 & 1.61 & 0.68 & 30069.16 & 33.51 & 246.66 \\
\hline Fertilizer type (FT) & 3 & $316.91 * *$ & $1.55^{* *}$ & $1.03 * *$ & 1023.42 & 11.04 & 45.56 \\
\hline Fertilizer level (FL) & 5 & $361.74 * *$ & $2.16 * *$ & $1.34 * *$ & $4096.80 * *$ & $29.57 * *$ & $671.17 * *$ \\
\hline $\mathrm{S} \times \mathrm{FT}$ & 3 & 101.48 & $1.49 * *$ & $0.93 * *$ & 1901.7 & 4.07 & $451.09 * *$ \\
\hline $\mathrm{S} \times \mathrm{FL}$ & 5 & $|22.6| *$ & 0.25 & 0.31 & 1431.77 & $17.65 * *$ & 165.32 \\
\hline $\mathrm{FT} \times \mathrm{FL}$ & 15 & $123.65 * *$ & $0.78 * *$ & $0.64 * *$ & $2251.38 * *$ & 2.59 & $182.85^{*}$ \\
\hline $\mathrm{S} \times \mathrm{FT} \times \mathrm{L}$ & 15 & $118.68 * *$ & $0.62 * *$ & $0.39 * *$ & $2349.43 * *$ & 2.56 & 95.88 \\
\hline
\end{tabular}


Table Continued...

\begin{tabular}{|c|c|c|c|c|c|c|c|}
\hline Source & df & Plant height & Number of leaves & Plant diameter & Leaf area & Plant biomass & Ear height \\
\hline Error & 92 & 38.57 & 0.17 & 0.14 & 949.26 & 4.96 & 80.2 \\
\hline R-Squarea & & 0.9 & 0.77 & 0.79 & 0.86 & 0.61 & 0.63 \\
\hline$C V$ & & 9.55 & 5.74 & 10.04 & 23.13 & 36.69 & 10.56 \\
\hline
\end{tabular}

*, ** significantly different at 0.05 and 0.0 I levels of probability, respectively, ANOVA

${ }^{\mathrm{a}} \mathrm{CV}=$ coefficient of variation, $\mathrm{R}$-Square $=$ coefficient of determination

Seasons, fertilizer types and levels had a highly significant effect on the agronomic traits measured (Table 3) while the season $\mathrm{x}$ fertilizer types, season $\mathrm{x}$ fertilizer levels show significant influence on the plant biomass, also, the fertilizer types and fertilizer levels interaction significantly improved all the agronomic parameters measured at five weeks after sowing.

Table 3 Mean squares from the analysis of variance showing the significant effect of fertilizer types and levels on agronomic growth parameters measure at 5 th week after sowing

\begin{tabular}{|c|c|c|c|c|c|c|}
\hline Source & df & Plant height (cm) & Number of Leaves & Plant girth (cm) & Leaves Area (cm) & Plant biomass $(\mathrm{cm})$ \\
\hline Season (S) & $\mathrm{I}$ & $99840.20 * *$ & $3.75^{*}$ & $10.280 * *$ & $2635345.04^{* *}$ & $8151.83 * *$ \\
\hline Replication(Season) & 4 & 2163.03 & 0.18 & 0.03 & 2715.49 & 567.58 \\
\hline Fertilizer Types (FT) & 3 & $864.96 *$ & I.78* & $2.374 * *$ & $30023.24 * *$ & $443.47 * *$ \\
\hline Fertilizer Levels (FL) & 5 & $1253.69 * *$ & $2.7 I^{*}$ & $2.497 * *$ & $16934.31 *$ & $|862.2| * *$ \\
\hline $\mathrm{S} * \mathrm{FT}$ & 3 & 256.47 & 0.6 & 0.485 & $|276| .57$ & $225.20 * *$ \\
\hline $\mathrm{S} * \mathrm{FL}$ & 5 & 209.28 & 0.73 & 0.309 & 8498.6 & $17 \mid .85^{*}$ \\
\hline $\mathrm{FT} * \mathrm{FL}$ & 15 & $563.18 * *$ & $1.27^{*}$ & $0.602 *$ & $17656.60^{* *}$ & 98.08 \\
\hline $\mathrm{S} * \mathrm{FT} * \mathrm{FL}$ & 15 & 202.43 & 0.75 & 0.364 & $15550.76 *$ & 69.34 \\
\hline Error & 92 & 238.91 & 0.65 & 0.305 & 7246.65 & 56.03 \\
\hline R-Square & & 0.85 & 0.49 & 0.62 & 0.83 & 0.82 \\
\hline CV & & 12.34 & 8.182 & 8.48 & 15.42 & 23.92 \\
\hline
\end{tabular}

*, ** significantly different from zero at 0.05 and 0.0 I level of probability, respectively. CV- coefficient of variation, R-Square- coefficient of determination

Mean separation effect on seasons, fertilizer types and levels at three and five weeks after sowing Table 4 . The effect of seasons was noticed on the number of leaves among the agronomic traits measured (Plant height, Number of leaves, Plant girth, leaves area and plant biomass) during the early stage of the crop. At the later stage (5 weeks after sowing) the number of leaves and plant girth significantly improved. During the late-season planting, plant height, plant girth, leaves area and plant biomass were better improve at 3 WAS while plant height, leaves area and plant biomass were significantly increased by late-season at 5 WAS.

Table 4 Means separation showing the effect of season, fertilizer types and levels on growth parameters

\begin{tabular}{|c|c|c|c|c|c|c|c|c|c|c|}
\hline & $3 w k$ & $3 w k$ & $3 w k$ & $3 w k$ & $3 w k$ & $5 w k$ & $5 w k$ & $5 w k$ & $5 w k$ & $5 w k$ \\
\hline \multirow[t]{2}{*}{ Treatment } & $\begin{array}{l}\text { Plant } \\
\text { height } \\
(\mathrm{cm})\end{array}$ & $\begin{array}{l}\text { No. of } \\
\text { leaves }\end{array}$ & Plant & $\begin{array}{l}\text { Leaves } \\
\text { Area }\end{array}$ & $\begin{array}{l}\text { Plant } \\
\text { biomass }\end{array}$ & $\begin{array}{l}\text { Plant } \\
\text { height }\end{array}$ & $\begin{array}{l}\text { No. of } \\
\text { leaves }\end{array}$ & Plant & $\begin{array}{l}\text { Leaves } \\
\text { Area }\end{array}$ & $\begin{array}{l}\text { Plant } \\
\text { biomass }\end{array}$ \\
\hline & & & Girth (cm) & $(\mathrm{cm})$ & (g) & $(\mathrm{cm})$ & & Girth (cm) & $(\mathrm{cm})$ & (g) \\
\hline \multicolumn{11}{|l|}{ Season } \\
\hline Early & 52.68 & 7.44 & 3.35 & 83.38 & 4.63 & 98.88 & 9.98 & 6.78 & 416.74 & 23.77 \\
\hline Late & 77.35 & 7.03 & 3.97 & 183.07 & 7.5 & $15 \mid .54$ & 9.65 & 6.25 & 687.3 & 38.82 \\
\hline LSD(0.05) & 2.17 & 0.15 & 0.12 & 10.2 & 0.74 & 1.99 & 0.27 & 0.18 & 28.17 & 2.48 \\
\hline
\end{tabular}


Table Continued..

\begin{tabular}{|c|c|c|c|c|c|c|c|c|c|c|}
\hline & $3 w k$ & $3 w k$ & $3 w k$ & $3 w k$ & $3 w k$ & $5 w k$ & $5 w k$ & $5 w k$ & $5 w k$ & $5 w k$ \\
\hline Treatment & $\begin{array}{l}\text { Plant } \\
\text { height } \\
(\mathrm{cm})\end{array}$ & $\begin{array}{l}\text { No. of } \\
\text { leaves }\end{array}$ & Plant & $\begin{array}{l}\text { Leaves } \\
\text { Area }\end{array}$ & $\begin{array}{l}\text { Plant } \\
\text { biomass }\end{array}$ & $\begin{array}{l}\text { Plant } \\
\text { height }\end{array}$ & $\begin{array}{l}\text { No. of } \\
\text { leaves }\end{array}$ & Plant & $\begin{array}{l}\text { Leaves } \\
\text { Area }\end{array}$ & $\begin{array}{l}\text { Plant } \\
\text { biomass }\end{array}$ \\
\hline & & & Girth (cm) & $(\mathrm{cm})$ & (g) & $(\mathrm{cm})$ & & Girth (cm) & $(\mathrm{cm})$ & (g) \\
\hline
\end{tabular}

Season

Fertilizer Types

\begin{tabular}{|c|c|c|c|c|c|c|c|c|c|c|}
\hline Urea & 69.17 & 7.5 & 3.85 & |40.| | & 5.37 & 121.99 & 9.96 & 6.63 & 541.94 & 27.73 \\
\hline NPK & 64.36 & 7.22 & 3.52 & 130.79 & 6.06 & 126.43 & 9.87 & 6.62 & 571.2 & 35.66 \\
\hline Organic & 62.12 & 6.99 & 3.76 & $|34.3|$ & 6.13 & $|20.8|$ & 9.49 & 6.13 & 515.92 & 29.34 \\
\hline Organomineral & 64.42 & 7.23 & 3.52 & 127.68 & 6.72 & 131.61 & 9.94 & 6.67 & 579.03 & 32.45 \\
\hline $\operatorname{LSD}(0.05)$ & 2.91 & 0.19 & 0.17 & 10.15 & 1.03 & 6.86 & 0.38 & 0.26 & 40.12 & 3.54 \\
\hline \multicolumn{11}{|l|}{ Fertilizer Levels } \\
\hline Okg/ha & 59.54 & 6.85 & 3.29 & 113.84 & 4.7 & 113.33 & 9.27 & 5.95 & 520.94 & 17.27 \\
\hline $25 \mathrm{~kg} / \mathrm{ha}$ & 64.54 & 7.09 & 3.6 & 130.5 & 5.47 & 124.72 & 9.69 & 6.69 & 538.92 & 26.1 \\
\hline 50 kg/ha & 65.06 & 7.29 & 3.53 & 134.56 & 6.08 & 128.64 & 9.7 & 6.46 & 565.42 & 31.52 \\
\hline 100 kg/ha & 71.3 & 7.57 & 3.92 & 151.26 & 7.19 & $|35.5|$ & 10.21 & 6.92 & 591.39 & 39.05 \\
\hline $125 \mathrm{~kg} / \mathrm{ha}$ & 66.5 & 7.56 & 3.87 & 142.94 & 7.57 & 123.84 & 10.07 & 6.57 & 565.4 & 41.43 \\
\hline $\operatorname{LSD}(0.05)$ & 3.56 & 0.24 & 0.21 & 12.4 & 1.26 & 8.41 & 0.46 & 0.32 & 49.13 & 4.33 \\
\hline
\end{tabular}

LSD, least significant difference

The effect of fertilizer types, the Urea fertilizer was noticed to be significantly increased all the growth traits except plant biomass which effect was showed on organomineral fertilizer at the early stage of planting ( 3 WAS) when compared with the other fertilizer treatments applied. During the late planting (5 WAS), it was observed that organomineral fertilizer treatment significantly improveplant height, plant girth and leaves area but plant biomass had its significant effect on NPK fertilizer, however, there was no statistical difference when compared with Urea and NPK while the number of leaves had no significant difference among the fertilizer treatments applied.

The effect of fertilizers levels, among the fertilizers levels $(0,25$, $50,75,100$, and $125 \mathrm{Kg} / \mathrm{ha}) 100 \mathrm{Kg} / \mathrm{ha}$ had significant effect in all the agronomic traits measured (Plant height, Number of leaves, Plant girth and leaves area) both at the early and late stage of the crop when compared with control plots except on the plant biomass where 125 $\mathrm{Kg} / \mathrm{ha}$ had significant effect when compared with $0,25,50$, and 75 $\mathrm{Kg} / \mathrm{ha}$.

The significant effect of fertilizer types and levels on yield and yield parameters from the analysis of variance Table 5. The effect of season affects all the yield parameters measured in this study while the fertilizer types affect ear length, number of row/ ear and number of kernel/row. The fertilizer levels had a highly significant effect on all the yield traits (ear weight, ear girth, and ear length, number of row /era and number of kernel/row). The interaction of fertilizer type with fertilizer levels showed significant improvement on ear weight, ear length and number of row/ear. More so, the interaction of season with fertilizer types also had a significant effect on all the parameters measured except ear girth and number of row/ kernel while the interaction of season with fertilizer levels and interaction of season with fertilizer types and with fertilizer levels revealed no significant effect on all the yield parameters investigated.

The interaction effect of fertilizer types and levels on the plant height Table 6. In all the amendments (Urea, NPK, Organic and Organomineral) and fertilizer levels $(0,25,50,75,100$ and $125 \mathrm{Kg} /$ ha) investigated, the interactions of fertilizer types with levels, NPK at $125 \mathrm{Kg} / \mathrm{ha}$ level had a significant effect on plant height when compared with other amendments and levels although, it is not statistically different from organomineral at $100 \mathrm{Kg} / \mathrm{ha}$.

Effect of fertilizer types and levels interaction on the number of leaves Table 7. NPK at $125 \mathrm{Kg} / \mathrm{ha}$ had the highest number of leaves and did not significantly different from Organominera at $100 \mathrm{Kg} / \mathrm{ha}$. While the Urea at $75 \mathrm{Kg} /$ ha had significant effect when compared with other treatments with lesser quantities of fertilizers types and levels.

Effect of fertilizer types and levels interaction on the plant girth Table 8. The significant plant girth was observed at $100 \mathrm{Kg} / \mathrm{ha}$ organomineral across the fertilizers types. While the leaf area was significantly different at NPK $125 \mathrm{Kg} / \mathrm{ha}$ across the fertilizers types and levels Table 9. 
Table 5 Mean squares from the analysis of variance indicating the effect of fertilizer type and level and season on yield and yield parameters

\begin{tabular}{lllllll}
\hline Source & df & Ear weight & Ear diameter & Ear length & NR/Eara & NK/Row \\
\hline Season (S) & $\mathrm{I}$ & $15.09 *$ & $836.63^{* *}$ & $603.233^{* *}$ & 0.12 & $63.50^{*}$ \\
Replication(season) (R) & 4 & 6.46 & 0.58 & 1.22 & 1.72 & 13.93 \\
Fertilizer Type (FT) & 3 & 4.82 & 1.36 & $2.935^{*}$ & $3.73^{* *}$ & 20.08 \\
Fertilizer levels (FL) & 5 & $32.29 * *$ & $3.30^{* *}$ & $6.122^{* *}$ & $2.21^{* *}$ & $44.76 * *$ \\
FT*FL & 15 & $6.55^{* *}$ & 1.23 & $2.189 *$ & $1.12^{* *}$ & 9.89 \\
S*FT & 3 & $7.85^{*}$ & 0.19 & $6.90^{* *}$ & 0.57 & $37.84^{*}$ \\
S*FL & 5 & 0.58 & 0.86 & 1.57 & 0.27 & 11.03 \\
S*FT*TL & 15 & 5.22 & 0.56 & 3.05 & 1.9 & 9.47 \\
Error & 92 & 2.68 & 0.81 & 1.04 & 0.4 & 9.88 \\
CV & & 10.1 & 5.96 & 6.54 & 4.97 & 9.08 \\
R-Square & & 0.63 & 0.92 & 0.89 & 0.68 & 0.49 \\
\hline
\end{tabular}

*,** significantly different from 0.05 and 0.01 level of probability, respectively

$\mathrm{NR} /$ Ear=number of rows per ear, NK/Row = numbers of kernels per row, CV = coefficient of variation, R-Square = coefficient of determination

Table 6 Effect of fertilizer types and levels interaction on the plant height $(\mathrm{cm})$

\begin{tabular}{llllll}
\hline Fertilizer level (kg:ha-I) & Urea & NPK & Organic & Organomineral & Standard Error \\
\hline 0 & 105.69 & 102.75 & 115.56 & 129.32 & 5.99 \\
25 & 119.76 & 125.63 & 129.21 & 124.28 & 1.95 \\
50 & 129.93 & 126.71 & 129.11 & 128.83 & 0.69 \\
75 & 125.24 & 119.63 & 123.9 & 132.04 & 2.57 \\
100 & 137.09 & 137.58 & 123.38 & 143.99 & 4.34 \\
125 & 114.24 & 146.24 & 103.71 & 131.16 & 9.37 \\
Standard error & 4.59 & 6.12 & 3.98 & 2.71 & \\
\hline
\end{tabular}

Table 7 Effect of fertilizer types and levels interaction on the number of leaves

\begin{tabular}{llllll}
\hline $\mathbf{K g} / \mathbf{h a}$ & Urea & NPK & Organic & Organomineral & Standard Error \\
\hline 0 & 9.5 & 9 & 8.75 & 8.83 & 0.24 \\
25 & 9.83 & 9.54 & 9.7 & 9.63 & 0.06 \\
50 & 10.2 & 9.42 & 9.71 & 9.42 & 0.2 \\
75 & 10.25 & 9.67 & 9.67 & 10.21 & 0.16 \\
100 & 10.08 & 10.33 & 9.75 & 10.67 & 0.19 \\
125 & 9.83 & 11.25 & 9.29 & 9.92 & 0.42 \\
Standard Error & 0.12 & 0.33 & 0.16 & 0.18 & \\
\hline
\end{tabular}

Table 8 Effect of fertilizer types and levels interaction on the plant diameter

\begin{tabular}{llllll}
\hline Kg/ha & Urea & NPK & Organic & Organomineral & Standard error \\
\hline 0 & 5.79 & 5.84 & 5.8 & 6.35 & 0.13 \\
25 & 6.95 & 6.8 & 6.37 & 6.5 & 0.11 \\
50 & 6.92 & 6.41 & 6.11 & 6.4 & 0.17 \\
75 & 6.82 & 6.25 & 6.04 & 6.88 & 0.21 \\
100 & 7.01 & 7.09 & 6.51 & 7.29 & 0.19 \\
125 & 6.3 & 7.32 & 5.94 & 6.7 & 0.3 \\
Standard error & 0.2 & 0.23 & 0.11 & 0.13 & \\
\hline
\end{tabular}

Citation: Ajibola OV, Ogunmola ON, Amujoyegbe JB. Efficacy of soil amendments on agronomic traits, yield and nutritional quality of Sweet Corn (Zea mays L. var. saccharata). Horticult Int J. 2020;4(4):96-106. DOI: I0.15406/hij.2020.04.00I66 
Table 9 Effect of fertilizer types and levels interaction on the leaves area of sweet corn

\begin{tabular}{llllll}
\hline Kg/ha & Urea & NPK & Organic & Organo mineral & Standard error \\
\hline 0 & 513.1 & 481.39 & 506.05 & 583.2 & 21.84 \\
25 & 503.11 & 578.01 & 555.82 & 518.77 & 17.08 \\
50 & 597.57 & 580.6 & 530.22 & 553.28 & 14.86 \\
75 & 547.04 & 510.32 & 507.49 & 555.41 & 12.349 \\
100 & 630.28 & 594.94 & 492.38 & 647.97 & 34.8 \\
125 & 460.52 & 681.95 & 503.58 & 615.54 & 50.76 \\
Standard error & 25.75 & 28.71 & 9.44 & 19.11 & \\
\hline
\end{tabular}

Means value of the significant effect of season, fertilizer types and levels on yield parameters Table 10. The effect of season on yield parameters was observed to be highly significant throughout the late planting season when compared with the early planting season except on the number of row per Ear. While the fertilizer types (Urea, NPK, Organomineral and Organic) effect on the yield parameters was noticed on all the parameters except on Organomineral (Ear weight),
NPK (Ear length, Number Kernel/Row) and Urea (Number of row/ Ear) while Ear girth was not significantly different from each other irrespective of the fertilizer types. The significant effect of fertilizer levels on the yield parameters was observed from $75 \mathrm{Kg} / \mathrm{ha}-125$ $\mathrm{Kg} / \mathrm{ha}$ while from $0 \mathrm{Kg} / \mathrm{ha}-50 \mathrm{Kg} / \mathrm{ha}$ had no significant effect. The highly significant effect of fertilizer level observed from the study is at $125 \mathrm{Kg} /$ ha across the yield parameter measured.

Table 10 Means value of the significant effect of season, fertilizer types and levels on yield parameters

\begin{tabular}{|c|c|c|c|c|c|}
\hline Levels & Ear weight (t/ha) & Ear diameter $(\mathrm{cm})$ & Ear length $(\mathrm{cm})$ & NR/Ear & NK/Row \\
\hline \multicolumn{6}{|l|}{ Season } \\
\hline Early & 15.9 & 12.69 & $|3.5|$ & $|2.7|$ & 34.12 \\
\hline Late & 16.54 & |7.5| & 17.6 & 12.76 & 35.45 \\
\hline LSD & 0.54 & 0.3 & 0.41 & 0.27 & 1.07 \\
\hline \multicolumn{6}{|l|}{ Fertilizer Type } \\
\hline Urea & $|6.6|$ & 15.12 & 15.67 & 12.25 & 35.74 \\
\hline NPK & 16.44 & 15.23 & 15.16 & 12.86 & 33.93 \\
\hline Organomineral & 15.83 & 15.24 & 15.58 & 12.93 & 34.64 \\
\hline Organic & 16 & 14.82 & 15.82 & 12.9 & 34.84 \\
\hline LSD & 0.77 & 0.42 & 0.48 & 0.3 & 1.47 \\
\hline \multicolumn{6}{|l|}{ Fertilizer levels } \\
\hline $0 \mathrm{~kg} / \mathrm{ha}$ & 14.39 & 14.58 & 14.9 & 12.5 & 32.51 \\
\hline $25 \mathrm{~kg} / \mathrm{ha}$ & 15.52 & 14.85 & 14.94 & 12.37 & 35.51 \\
\hline $50 \mathrm{~kg} / \mathrm{ha}$ & 16.07 & 15.08 & 15.78 & 12.97 & 33.7 \\
\hline $75 \mathrm{~kg} / \mathrm{ha}$ & 16.55 & 15.17 & 15.73 & 12.54 & 35.42 \\
\hline $100 \mathrm{~kg} / \mathrm{ha}$ & 17.33 & 15.27 & 16.02 & 12.92 & 35.63 \\
\hline $125 \mathrm{~kg} / \mathrm{ha}$ & 17.46 & 15.67 & 15.97 & 13.12 & 35.94 \\
\hline LSD & 0.94 & 0.52 & 0.58 & 0.36 & 1.8 \\
\hline
\end{tabular}

NR/Ear- number of row per cob, NK/Row- numbers of kernel per row, LSD- least significant difference

Effect of fertilizer types and levels interaction on the ear weight yield Table 11. The interaction effect was noticed at level $125 \mathrm{Kg} /$ ha when NPK fertilizer was applied. At $125 \mathrm{Kg} / \mathrm{ha}$ had the highest ear weight when compared with other fertilizer types and levels. The interaction effect of fertilizer types and levels on Ear length (Table 12) and Row/Ear (Table 13) was noticed on the organic type of fertilizer applied at the levels of $125 \mathrm{Kg} / \mathrm{ha}$.
Interaction effect of season and fertilizer types on Ear Weight Figure 1. Among the fertilizer types and season, it was observed that Urea type of fertilizers had a significant effect during the early planting season while NPK fertilizer showed noticeable effect during the late season and did not significantly different from the Urea fertilizer applied during the early planting season. 
Table I I Effect of fertilizer types and levels interaction on the ear weight yield

\begin{tabular}{llllll}
\hline Kg/ha & Urea & NPK & Organic & Organo mineral & Standard error \\
\hline 0 & 14.21 & 14.71 & 14.71 & 13.95 & 0.19 \\
25 & 16.56 & 15.45 & 15.44 & 14.62 & 0.4 \\
50 & 16.78 & 15.08 & 15.8 & 16.6 & 0.39 \\
75 & 18.01 & 15.98 & 16.31 & 15.92 & 0.49 \\
100 & 17.33 & 17.59 & 16.18 & 18.23 & 0.43 \\
125 & 16.75 & 19.85 & 17.57 & 15.65 & 0.89 \\
Standard error & 0.53 & 0.79 & 0.39 & 0.62 & \\
\hline
\end{tabular}

Table 12 Effect of fertilizer types and fertilizer levels interaction on ear length

\begin{tabular}{llllll}
\hline Kg/ha & Urea & NPK & Organic & Organomineral & Standard error \\
\hline 0 & 15.26 & 15.13 & 14.33 & 14.86 & 0.21 \\
25 & 16.08 & 13.17 & 15.55 & 14.97 & 0.63 \\
50 & 15.13 & 15.66 & 16.31 & 16.01 & 0.25 \\
75 & 15.66 & 15.5 & 15.86 & 15.9 & 0.09 \\
100 & 16.05 & 15.75 & 16.27 & 16.01 & 0.11 \\
125 & 15.817 & 15.72 & 16.63 & 15.7 & 0.22 \\
Standard error & 0.16 & 0.41 & 0.34 & 0.21 & \\
\hline
\end{tabular}

Table I 3 Effect of fertilizer types and levels interaction on the number of rows per ear

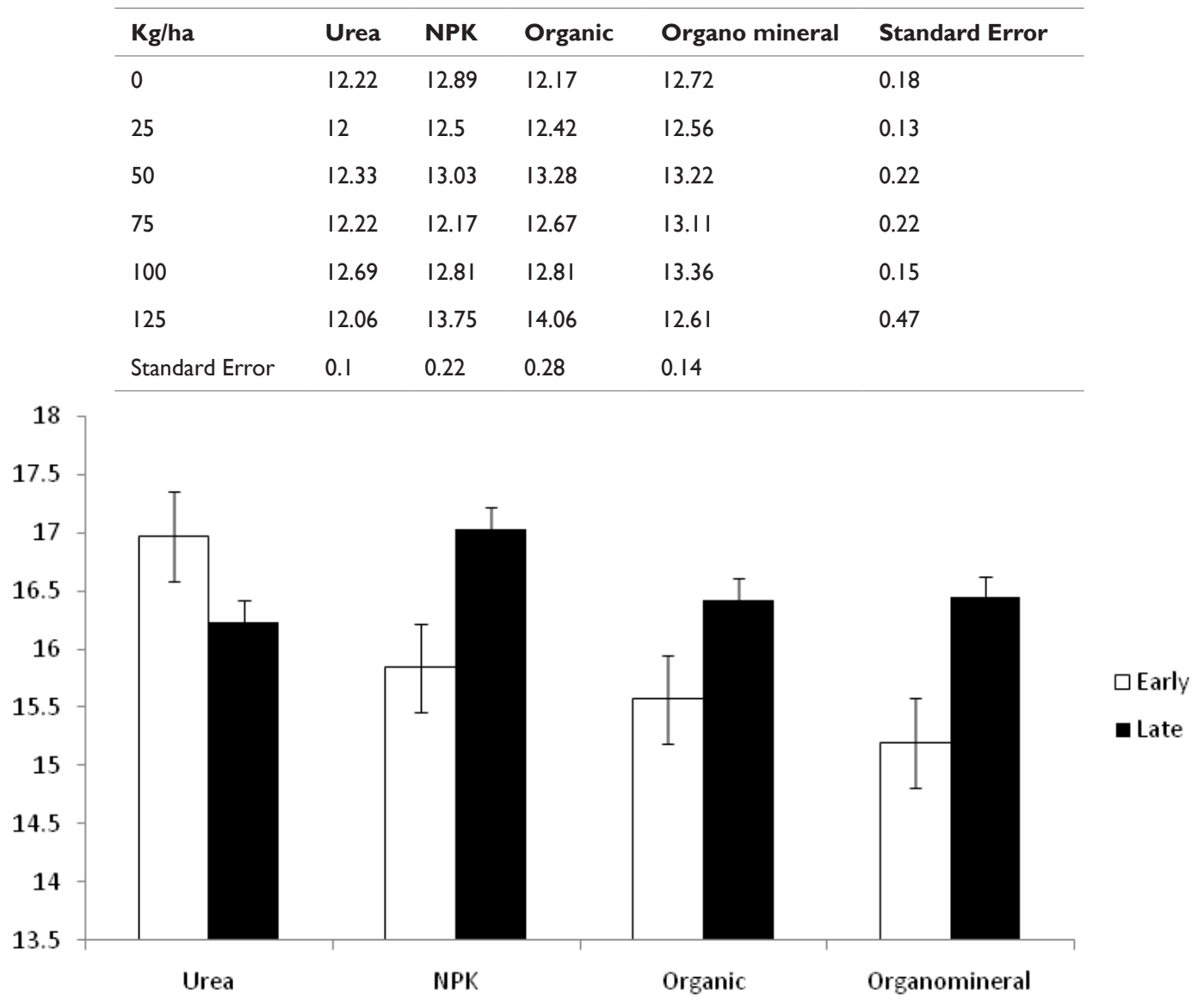

Figure I Effect of season and fertilizer types interaction on the Ear weight yield. 


\section{Influence of fertilizer types and levels on:}

The total sugar content of sweet corn Figure 2. The effect of different types of fertilizer and levels on the sugar content of sweetcorn was observed to be significantly different in NPK fertilizer type at $100 \mathrm{Kg} / \mathrm{ha}$ when compared with the other soil amendments and levels of application.

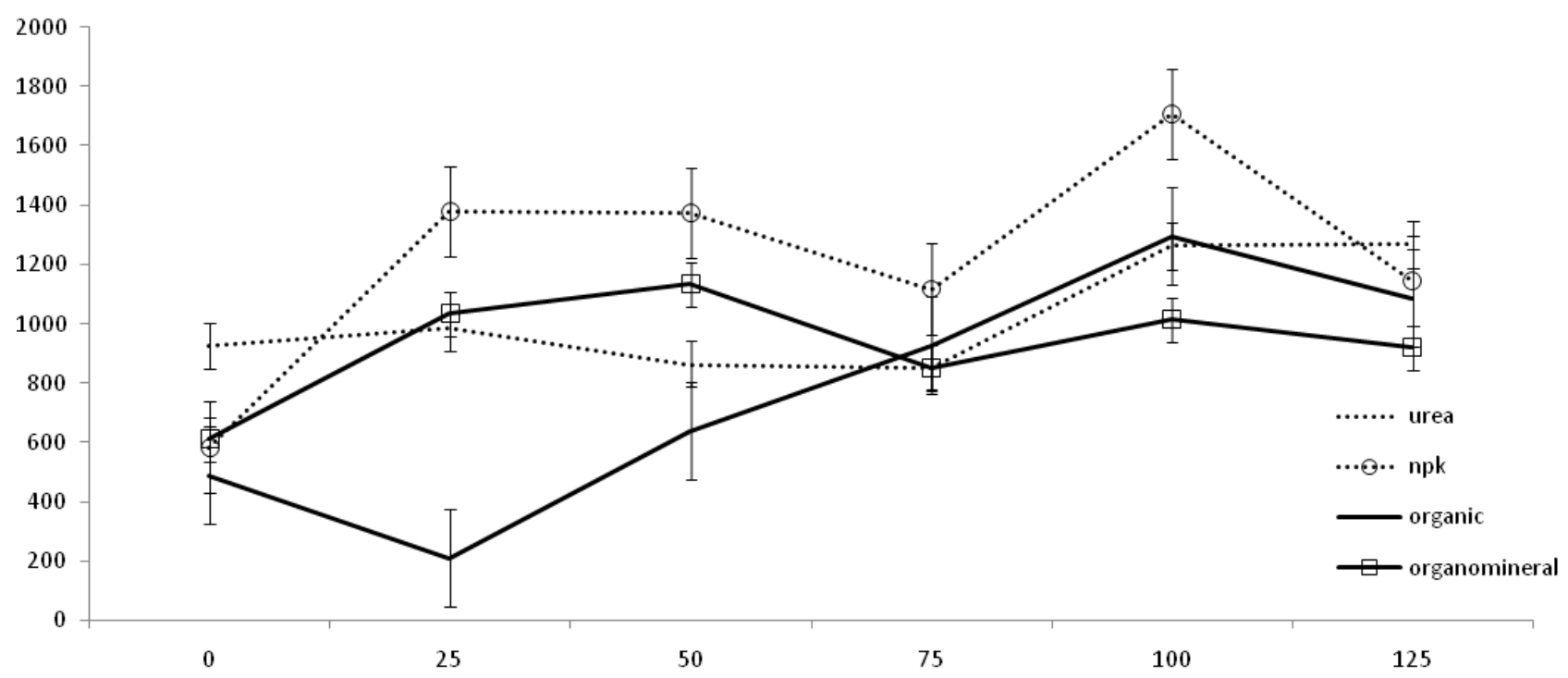

Figure 2 Influence of fertilizer types and levels on the total sugar content of sweet corn.

Ether extractof sweet corn Figure 3. Was noticed on Organomineral type of fertilizers at $100 \mathrm{Kg} / \mathrm{ha}$.

The crude fibre content of sweet corn Figure 4. Among the fertilizer types, Organic form of fertilizer had a noticeable effect at 25 $\mathrm{Kg} / \mathrm{ha}$ when compared with other fertilizers and levels studied. The organic form of fertilizer at $25 \mathrm{Kg} /$ ha did not significantly different from Organomineral fertilizer at $100 \mathrm{Kg} / \mathrm{ha}$.
Ash content of sweet corn Figure 5. The plots without the fertilizersapplication significantly improved the Ash content of sweet corn.

Crude protein of sweet corn Figure 6. Among the fertilizers type and levels, Urea at $75 \mathrm{Kg} / \mathrm{ha}$ level had the highest percentage of crude protein however, there were no significant differences among the fertilizers applied at $75 \mathrm{Kg} / \mathrm{ha}$.

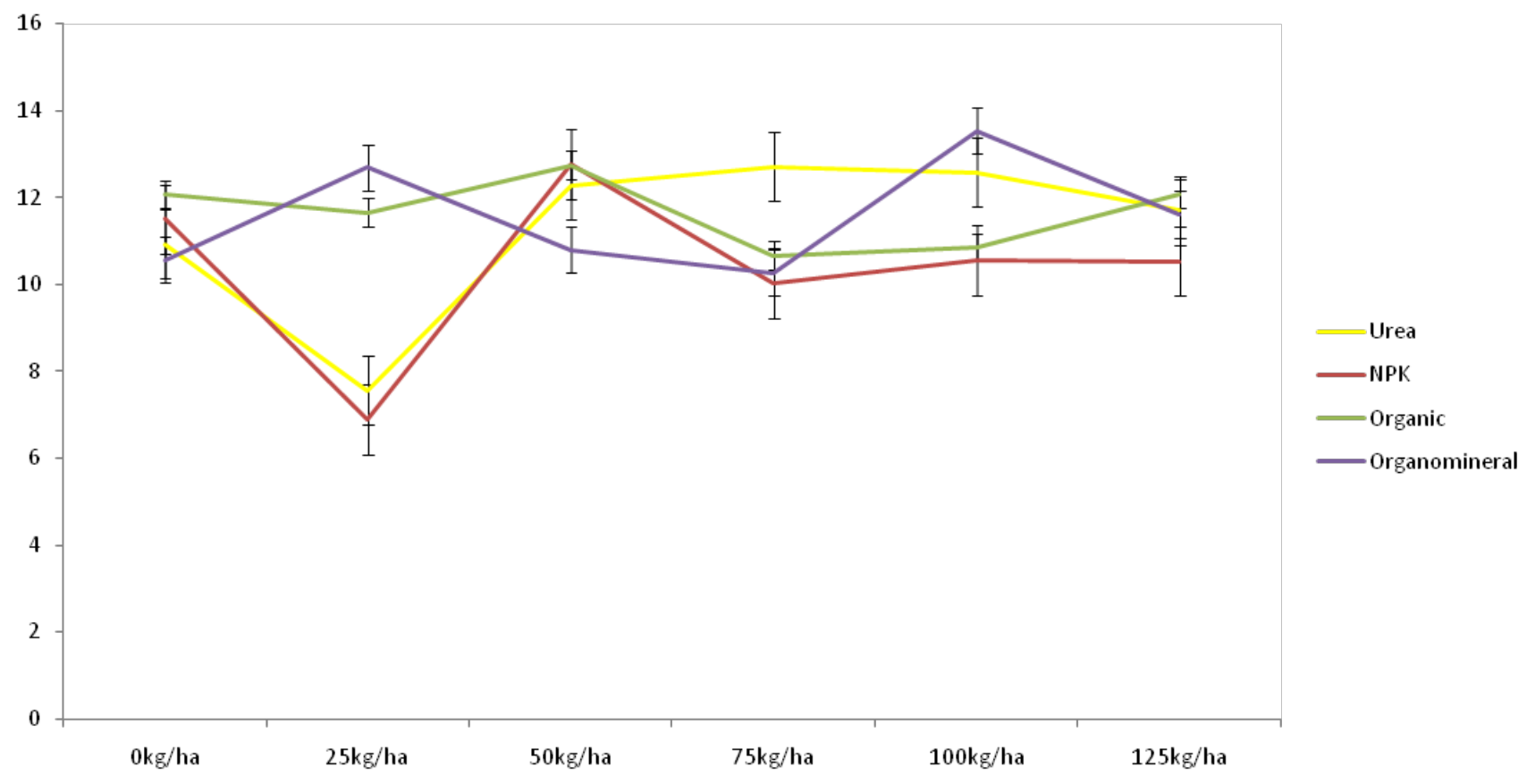

Figure 3 Influence of fertilizer types and levels on the ether extract of sweet corn. 


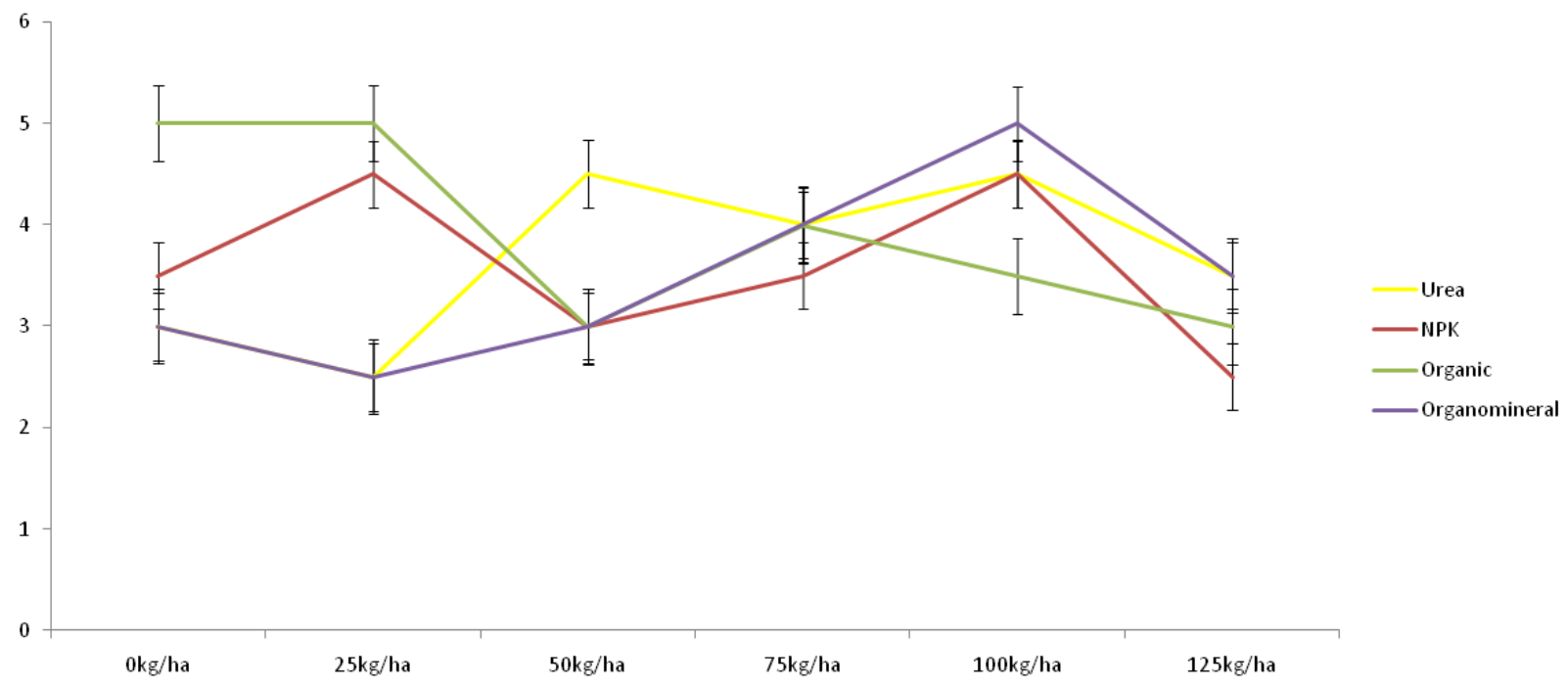

Figure 4 Influence of fertilizer types and levels on the Crude fiber content of sweet corn.

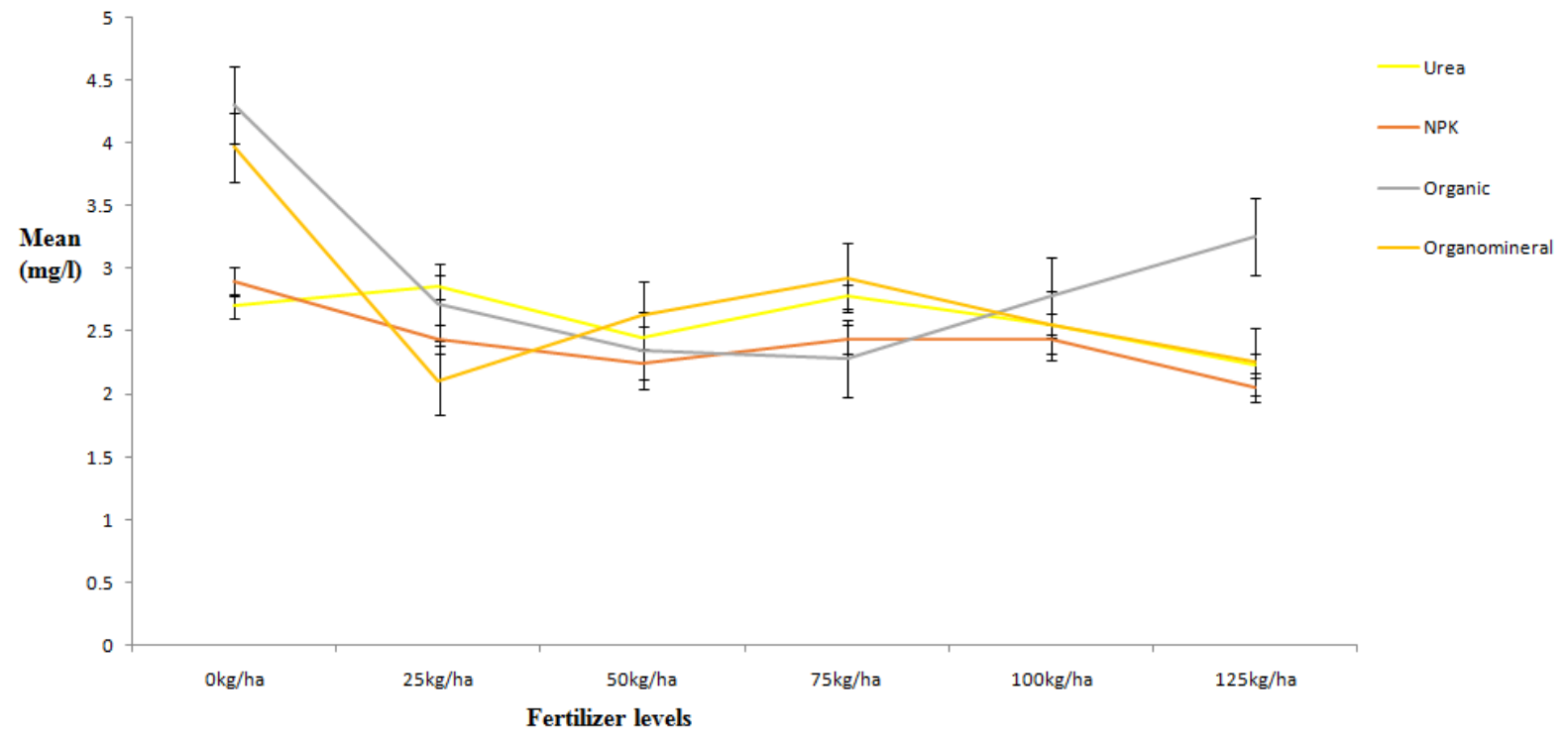

Figure 5 Influence of fertilizer types and levels on the Ash content of sweet corn.

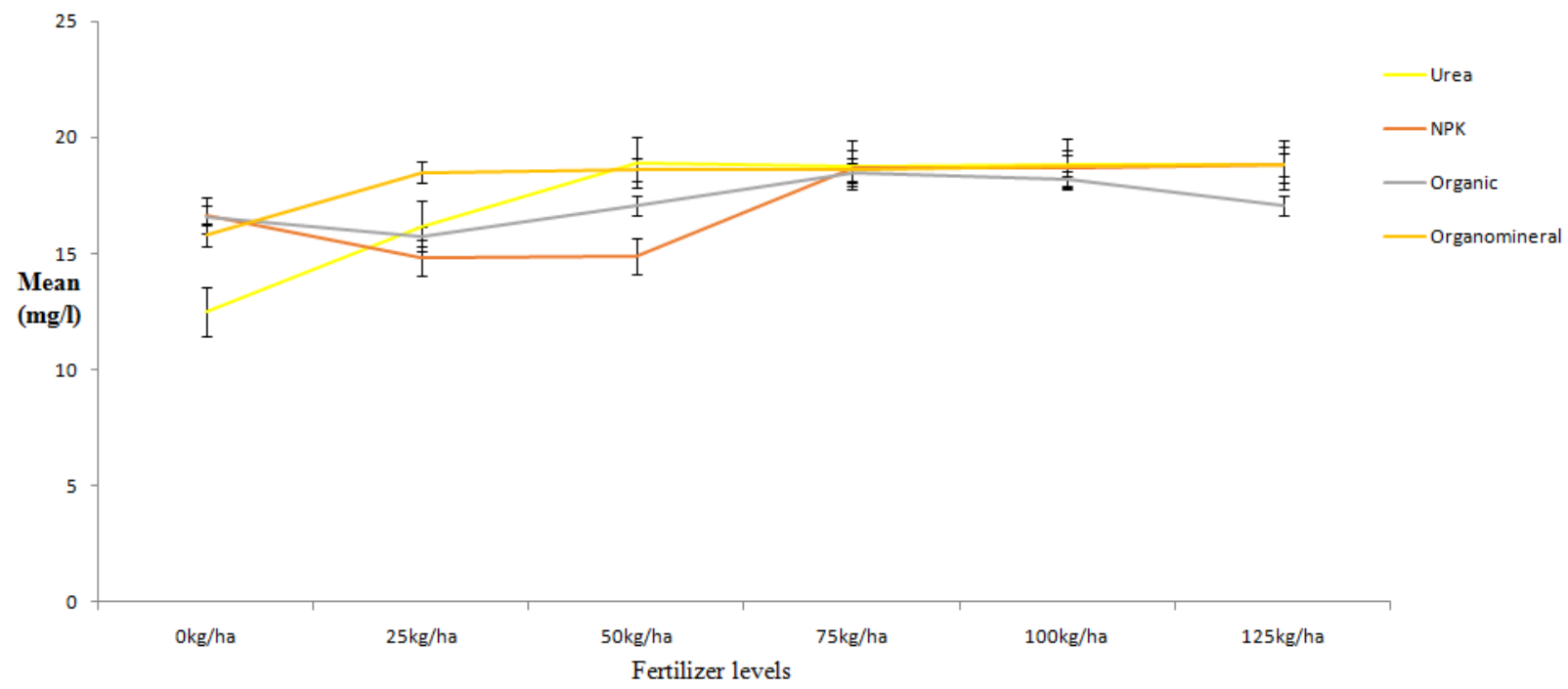

Figure 6 Influence of fertilizer types and levels on the crude protein of sweet corn. 
The moisture content of sweet corn Figure 7. The application of fertilizer at any levels did not have any effect on the moisture content on sweetcorn irrespective of fertilizer types or levels.

The total carbohydrate of sweet corn Figure 8. There was a highly significant difference among the fertilizer types and levels applied. NPK form of fertilizer type significantly different from other fertilizers type while at $25 \mathrm{Kg}$ /ha significantly different from other levels studied.

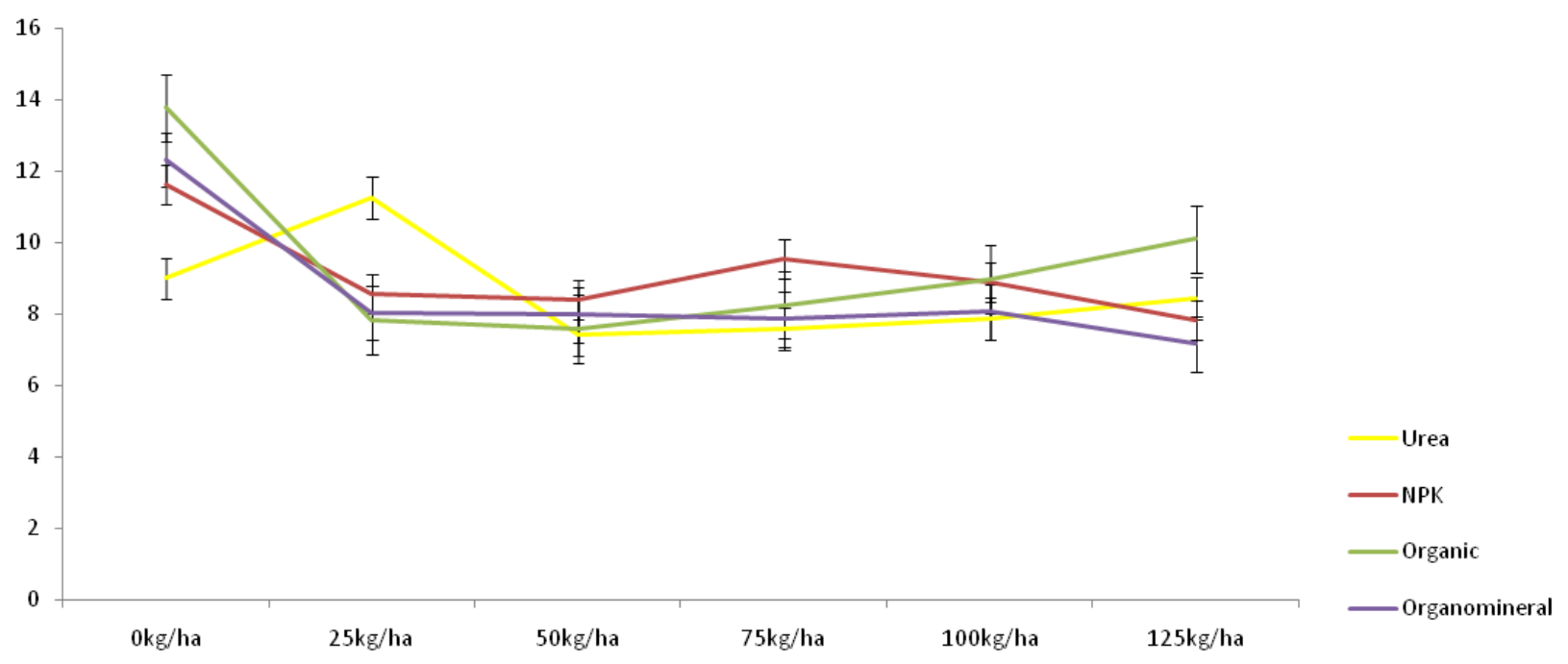

Figure 7 Influence of fertilizer types and levels on the moisture content of sweet corn.

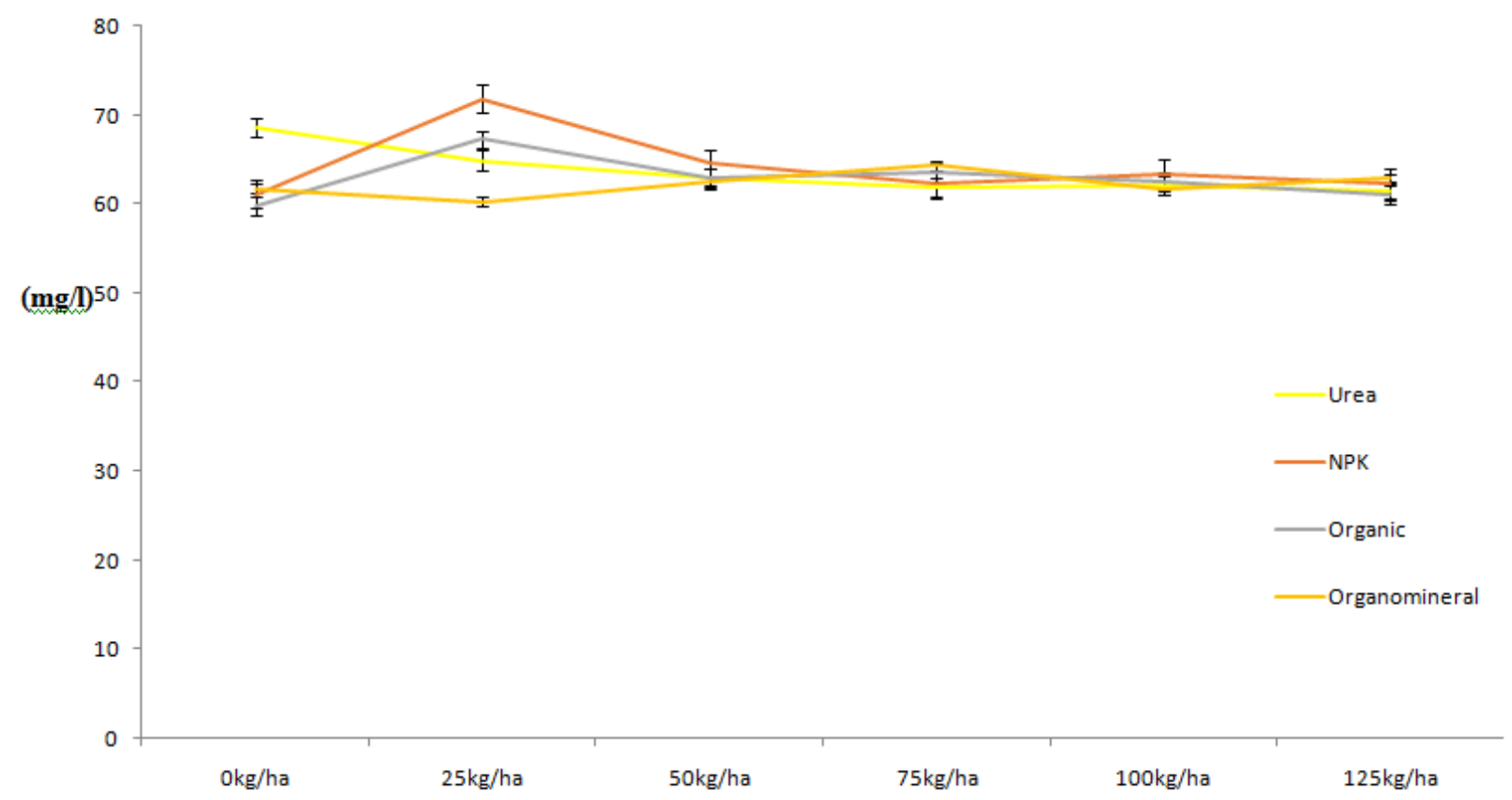

\section{Fertilizer levels}

Figure 8 Influence of fertilizer types and levels on the total carbohydrate of sweet corn.

\section{Discussion}

The results of the studies indicate that season has a positive effect on the agronomic parameters investigated. During the late cropping season Plant height, Plant Girth, Leaves Area, and Plant biomass were enhanced due to the limited erosion and runoff at the late cropping season which resulted to minimizing the rate at which the fertilizers amendment reduces the leaching rate compared with early cropping season which made the plants to use the available nutrients around the root zones. The premise to the above results, sweetcorn yield parameters were significantly higher during the late cropping season. It could be concluded that late-cropping season favour's the agronomics and yield of sweet corn.

The influence of fertilizer types and levels on the growth and development of sweet corn shows that both the agronomic and yield 
parameters were improved by NPK fertilizer when compared with other nutrient amendments. This result is not far-fetched from the different types of fertilizer element combine (Nitrogen + Potassium + Calcium) to form a nutrient amendment which therefore helps to enhance the limited nutrients in the soil. The positive effect of fertilizer types and levels on the growth and development of sweet corn observe from this studies confirmed the report of ${ }^{17}$ and that different fertilizer types have different rate at which they release the nutrient to the soil. The significant effect of organic fertilizer having produced the better cob length could be as a result of gradual releases of nutrient into the soil without been washed away by runoff or erosion. Though the fertilizer types have no significant effect on the cob weight yield, but significantly influence the cob length and the number of kernel per row, however, there was an increase in the cob weight yield and the other yield component as the fertilizer levels increases this confirm the report of ${ }^{18}$ that low yields were achieved representing a treat to the profitability of production when no fertilizer was applied in sweet corn production. Also, there was an increase in the cob weight yield and yield component as the fertilizer levels increases this confirm the report of ${ }^{18}$ that low yields were achieved representing a treat to the profitability of production when no fertilizer was applied in sweet corn production. in addition, It was also reported by ${ }^{19}$ that in Nigeria sweet corn maximally produce fresh cob weight and dry matter with rate $120 \mathrm{Kg} / \mathrm{ha}$ in compare with other rates $(0,40,80 \mathrm{~kg} / \mathrm{ha})$.

The NPK $100 \mathrm{~kg} /$ ha fertilizer type and level significantly influence the total sugar concentration and the ether extract of sweet corn this confirms the report of ${ }^{20}$ that nitrogen in sweet corn growing is an important component influencing both the yield and amino acids, which in turn decide the taste and nutrient value of kernels.

\section{Acknowledgments}

None.

\section{Conflicts of interest}

Authors declare no conflict of interest exists.

\section{References}

1. Pangaribuan DH, Hendarto $\mathrm{K}$. The effect of organic fertilizer and urea fertilizer on growth, yield and quality of sweet corn and soil health. Asian Journal of Agriculture and Biology. 2018;6(3):335-344.

2. Olaoye CO, Asaolu TO, Adewoye JO. Review of revenue generation in nigeria local government; a case study of ekiti state. International Business Management. 2009;3(3):54.

3. Fekonja M, F Bavec, S Grobelnik-Mlakar, et al. Growth performance of sweet maize under non-typical maize growing conditions. Biological Agriculture and Horticulture. 2011;27(2):147-164.

4. Genc L, M Inalpulat, U Kizil, et al. Determination of water stress with spectral reflectance on sweet corn (Zeamays L.) using classification tree (CT) analysis. Zemdirbyste-Agriculture. 2013;100(1):81-90.

5. Elemo KA. Maize (Zea mays L.) agronomy research in the Nigerian savanna. Maize: improvement, production, and utilization in Nigeria. $993 ; 105-117$.
6. Termeer WC, PR Warman. Analysis of racetrack, yard waste and sewage sludge compost and evaluation as a soil amendment and growth medium. Proceedings 14th Annual Meeting, Composting Council of Canada, Toronto, Canada. 1994.

7. Jibrin JM, M Sarkin-Fulani. Response of Sweet Corn (Zeamayssaccharata) to levels of nitrogen and phosphorus in Sudan Savanna of Nigeria. Savaanah Journal of Agriculture. Faculty of Agriculture, Bayero University Kano. 2011;6:108-119.

8. Ajibola OV, BJ Amujoyegbe. Effect of seasons, mulching materials, and fruit quality on a Cucumber (Cucumis sativus L.) variety. Asian Journal of Agricultural and Horticultural Research. 2019;3(2):1-11.

9. Viswanatha GB, BK Ramachandrappa, HV Nanjappa. Soil-plant water status and yield of sweet corn (Zeamays L. var. saccharata) as influenced by drip irrigation and planting methods. Agricultural Water Management. 2002;55(2):85-91.

10. Hayati M, R Hayati. Result of several clone of Sweet Potato (Ipomoeabatatas L.) in Middle East on the influence of phosfor fertilizer dosage and clone types. UNEJ e-Proceeding. 2018;193-200.

11. Pangaribuan DH, Hendarto K. The effect of organic fertilizer and urea fertilizer on growth, yield and quality of sweet corn and soil health. Asian Journal of Agriculture and Biology. 2018;6(3):335-344.

12. Ramadhani RH, Roviq M, Maghfoer MD. Pengaruh sumber pupuk nitrogen dan waktu pemberian urea pada pertumbuhan dan hasil tanaman jagung manis (Zea mays Sturt. var. saccharata). Jurnal Produksi Tanaman. 2016;4(1).

13. Herpstead MT. The classification of some Nigerian soils. Soil Sci. 1973;116:437-443.

14. AOAC (Association of Analytical Chemists). Official methods of analysis. 2000.

15. Musa AK, Lawal MT. Effects of different concentrations of four spices on the adult mortality and emergence of maize weevil, sitophilus zeamais motschulsky (Coleoptera: Curculionidae). Crop Research. 2019;54(1and2);53-57.

16. Steel RGD, Torrie JH. Principles and procedures of statistics. McGrawHill Book Co.Int. Int. New York, 276 pp. Agricultural Science. 1987;18(5):668-674.

17. Mosier AR, Syers JK, Freney JR. Nitrogen fertilizer: an essential component of increased food, feed, and fiber production. Agriculture and the nitrogen cycle: assessing the impacts of fertilizer use on food production and the environment. 2004;65:3-15.

18. Orosz Ferenc, Jakab S, Losak T, et al. Effect of fertilizer application to sweet corn (Zea mays) grown on sandy soil. Journal of Environmental Biology. 2009;30(6):933-938.

19. Olaniyan AB, Akintoye HA, Balogun MA. Effect of different sources and rates of nitrogen fertilizer on growth andyield of sweet corn. 2003.

20. Dale E. Sweet corn nitrogen fertilization. oswego country vegetable program news, cornell cooperative extension. 1995;25:6.

21. SAS (Statistical Analysis System) Version 9.1. SAS Institute Inc., Cary, NC. 2003. 